\title{
SEGREGATION OF THE RR BIOTECHNOLOGY AND AGRONOMICAL VARIABLES IN SINGLE-CROSS, DOUBLE-CROSS, AND F2 HYBRIDS OF MAIZE (ZEA MAYS L.)
}

\author{
Guilherme Gallas Salvalaggio 1, Eduardo Franz Berkenbrock 1, Jhonatan Rafael \\ Wendling Hartmann Hister 1, Eliane Cristina Gruszka Vendruscolo 2 iD, Hendrel \\ Vinícius Richter Assis ${ }^{1}$, Vivian Carré Missio ${ }^{1}$ iD, Alan Gregório Martins ${ }^{3}$, Robson \\ Fernando Missio *1 1 iD \\ *1 Department of Agronomic Sciences, Federal University of Paraná, Palotina, Paraná, Brazil \\ 2 Labiogen- Laboratory of Biochemistry and Genetics, Federal University of Paraná, Palotina, \\ Paraná, Brazil \\ 3 Postgraduate Student in Biotechnology, Federal University of Paraná, Palotina, Paraná, Brazil
}

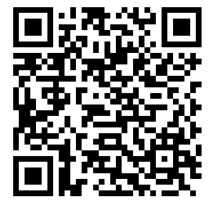

DOI: https://doi.org/10.29121/granthaalayah.v8.i10.2020.2113

Article Type: Research Article

Article Citation: Guilherme Gallas Salvalaggio, Eduardo Franz Berkenbrock, Jhonatan Rafael Wendling Hartmann Hister, Eliane Cristina Gruszka Vendruscolo, Hendrel Vinícius Richter Assis, Vivian Carré Missio, Alan Gregório Martins, and Robson Fernando Missio. (2020). SEGREGATION OF THE RR BIOTECHNOLOGY AND AGRONOMICAL VARIABLES IN SINGLE-CROSS, DOUBLE-CROSS, AND F2 HYBRIDS OF MAIZE (ZEA MAYS L.). International Journal of Research -GRANTHAALAYAH, 8(10), 338-349. https://doi.org/10.29121/granthaa layah.v8.i10.2020.2113

Received Date: 16 October 2020

Accepted Date: 31 October 2020

Keywords:

Productivity

Segregation

Cost-Benefit

Pirate Seeds

Home-Breeding

\section{ABSTRACT}

The present work evaluated the segregation of the RR-biotechnology and the agronomic performance of maize hybrids originated from three seed categories: single-cross commercial hybrids, double-cross hybrids, and saved seeds (F2 population). The experiment was set up in the field, within a producing area used for market purposes, in São Miguel do Iguaçu, Paraná, Brazil. The research followed a randomized block design with four repetitions. We investigated the following treatments: saved seeds/F2 population (MG 580 PW, MG 30A37 PW, MG $600 \mathrm{PW}$, and MG $545 \mathrm{PW}$ ), seeds of single-cross commercial hybrids (MG $580 \mathrm{PW}$, MG 30A37 PW, AS 1777 PRO3, AG 9000 PRO3, and DKB 290 PRO3) and home-bred seeds/double-cross hybrids (DKB 290 PR03 x MG 30A37 PW, DKB 290 PR03 x DKB 285 PEO3, DKB 290 PRO3 x DOW 2B587 PW, and DKB 290 PRO3 x MG 600 $\mathrm{PW}$ ). The study considered agronomical characters, as well as the segregation of the RR-biotechnology. The hybrids MG 580 PW and DKB 290 PRO3 were the most productive ones, yielding 9,244.31 and 9,151.84 kg ha-1, respectively. The groups formed by double-cross and F2-population hybrids had the highest average values of RR-biotechnology segregation (20.5\% and $13 \%$, respectively). The group of commercial hybrids proved to be superior to the others in all variables appraised, and they also did not show segregation of the RR-biotechnology. The principal component analysis made it possible to sort the three categories of seeds. In conclusion, despite the high cost, the commercial seeds stood out showing the best cost-benefit for maize crops. 
Segregation of The Rr Biotechnology and Agronomical Variables in Single-Cross, Double-Cross, And F2 Hybrids of Maize (Zea Mays L.)

\section{INTRODUCTION}

Maize (Zea mays L.) is a type of grass, member of the family Poaceae, whose evidence of use dates back 7,000 years B.C.E. Mexico and Guatemala are said to hold its origin but, nowadays, maize is grown and consumed in all continents (DUARTE et al., 2015). According to the Council for Biotechnological Information (2010), humankind first started to domesticate and enhance the plant through visual selection in the field, aiming at characteristics such as productivity, resistance to diseases and environmental adaptation, which led to the varieties known today.

Maize culture has enormous socioeconomic importance to Brazil, as the country places third in the worldwide production, accounting for 97 million tons of grains in the 2017/ 2018 crop (CONAB, 2018). Such productivity is the consequence not only of a vast area of cultivation, but also of a diverse market demand, which includes animal feeding (poultry, cattle and pig farming), human food, oil extraction, other industrial goods, and exportation (ALESSI et al., 2009).

Since the 20th century, many breeding programs have been created to introduce new characteristics to maize culture, in order to improve productivity and the adaptability to different regions, soil conditions, climates, and purposes of use (PEREIRA FILHO et al., 2008). This became feasible through the development of pure lineages, via self-pollination, or new hybrids by cross-breeding different varieties of great yield potential, which could contribute to a substantial increment in grain production (BERNINI, 2011).

Genetic enhancements were applied to seed quality attributes, such as physical, physiological, and sanitary aspects that directly affect the ability to form plants and crops with high productivity. Therefore, seeds became the most valuable asset to implementing cultures, as they are paramount to guarantee the success and the yield of agricultural activities (MARTIN et al., 2007).

Seed companies have specialized themselves in producing commercial maize seeds, and have set up fields exclusively to conduct breeding ventures that would guarantee genetic identity and quality. The techniques employed in these cases include the multiplication of lineages, the cultivation of male and female individuals in the same area, isolation of production fields, sowing at proper seasons and climatic conditions, intensive use of fertilization, systematic prevention of weeds, plagues and diseases, and implementation of adequate storage conditions (PEREIRA FILHO et al., 2008). So, companies assume the responsibility in the eventuality of any problem related to qualitative features of the seeds (SILVA, 2011).

Once these methods are followed through, it becomes possible to obtain some certification that will assure the fulfillment of the genetic potential and expected quality. According to Silva (2011), such accreditation processes comprise inspections in the field and during the processing phase. That way, companies can assume the responsibility in the eventuality of any problem related to qualitative features of the seeds.

On the other hand, Lacey (2000) claims that some farmers disregard the potential of good commercial seeds. They often continue to use the so-called pirate seeds, which had been saved from previous crops or that had been acquired from neighbors- who do not select their grains either. It is recognized that the open cross-pollination is typical in maize. In cases that the self-pollination is favored, as when saved seeds are employed, genetic and phenotypic segregation of characteristics tends to occur, contributing to diminishing plant vigor and crop productivity (GODOI, 2008). A similar situation happens to breeding maize at home from commercial single-cross hybrids. The resulting double-cross hybrids normally have high genetic variability, less plant uniformity and lower productivity to those of single- and triple-cross hybrids. On top of that, there is always the risk of contamination, as the advised production techniques are not followed strictly.

As divulged by ABRASEM (2019), the illegal commercialization of seeds not only amass an annual deficit of \$600 million for the agribusiness, but also conspires against the high technological level employed in Brazilian crops. Since the problem also affects other major cultures, Brazil is the Latin-American nation with the highest rate of seed piracy. In fact, $30 \%$ of all seeds used in the country are estimated to be illegal or pirate (ABRASEM, 2019).

Therefore, bearing in mind the superiority of commercial seeds and the guarantee they convey over the pirate ones (from home breeding/double-cross hybrids, or saved from previous crops/F2 population), this study aimed at evaluating the segregation of the RR biotechnology (Roundup Ready) and of other agronomical characters among maize hybrids from three categories, in field conditions. 
Guilherme Gallas Salvalaggio, Eduardo Franz Berkenbrock, Jhonatan Rafael Wendling Hartmann Hister, Eliane Cristina Gruszka Vendruscolo, Hendrel Vinícius Richter Assis, Vivian Carré Missio, Alan Gregório Martins, and Robson Fernando Missio

\section{MATERIALS AND METHODS}

The experiment was carried out in São Miguel do Iguaçu, Paraná, Brazil (2524'25.32” S, 5410'23.97” 0, 293 m altitude). The predominant local climate, according to the Köeppen and Geiger's classification (1948), is the Cfa Humid Subtropical (mesothermal), with an average annual temperature of $20{ }^{\circ} \mathrm{C}$, a non-defined dry season, hot summers, sporadic frosts in the winter, and rainfall rounding 1,700 $\mathrm{mm}$ per year. The soil is mostly Eutroferric Red Latosol, with $77.45 \%$ clay, $10.25 \%$ sand, $12.30 \%$ silt and the nutritional conditions disclosed by the soil analysis.

The experiment followed a randomized block design (RBD), with 13 treatments (Table 1) and four blocks, totalizing 52 experimental parcels. The assay was set up along sowing lines, with parcels composed of four 5-meterlong lines. The useful area comprised the two central lines, disregarding $0.50 \mathrm{~m}$ from borders.

Seeds of all the categories were exposed to the insecticide Cruiser® (Thiamethoxam, $120 \mathrm{~mL}$ for 60,000 seeds and $800 \mathrm{~mL} 100 \mathrm{~g}^{-1}$ of seeds), to eliminate any existing soil plague. A standard quantity of $1 \mathrm{~kg}$ of seeds from each cultivar was homogenized with $8 \mathrm{~mL}$ of the insecticide mixture. Additionally, a base chemical fertilization was also applied, considering $290 \mathrm{~kg}$ ha-1 of the formulation 10-15-15+11 (NPK+S). Further agricultural procedures were performed according to recommendations for maize culture (CRUZ et al. 2007).

The evaluations began 20 days past sowing, with the counting of the plant stand initially established. After handling the weeds, the plants susceptible to the herbicide glyphosate, which present themselves as wilted or even dead, were quantified. The goal was to assess the percentage of maintenance of the RR biotechnology in the different treatments, as a result of segregation in double-cross hybrids (from home breeding) and in F2 population (cultivars saved from self-production). These plants do not present the protein CP4 EPSPS (originated from Agrobacterium sp., strain CP4), and show little affinity to glyphosate, in comparison with other enzymes EPSPS (PIONEER, 2019).

Table 1: Description of the treatments.

\begin{tabular}{|c|c|c|c|}
\hline Hybrid & Technology & Company/Category & Description \\
\hline MG 580 PW SS* & PowerCore ${ }^{\mathrm{TM}}$ & Saved seed & F2 Population \\
\hline MG 30A37 PW SS & PowerCore ${ }^{\mathrm{TM}}$ & Saved seed & F2 Population \\
\hline MG 600 PW SS & PowerCore ${ }^{\mathrm{TM}}$ & Saved seed & F2 Population \\
\hline MG 545 PW SS & PowerCore ${ }^{\mathrm{TM}}$ & Saved seed & F2 Population \\
\hline MG 580 PW & PowerCore ${ }^{\mathrm{TM}}$ & MORGAN/Commercial & Single-cross hybrid \\
\hline MG 30A37 PW & PowerCore ${ }^{\mathrm{TM}}$ & MORGAN/Commercial & Single-cross hybrid \\
\hline AS 1777 PR03 & VT PRO3® & AGROESTE/Commercial & Single-cross hybrid \\
\hline AG 9000 PRO3 & VT PRO3® & AGROCERES/Commercial & Single-cross hybrid \\
\hline DKB 290 PRO3 & VT PRO3® & DEKALB/Commercial & Single-cross hybrid \\
\hline DKB 290 PR03 x MG 30A37 PW & VT PRO3® & Home breeding & Double-cross hybrid \\
\hline DKB 290 PRO3 x DKB 285 PRO3 & VT PRO3® & Home breeding & Double-cross hybrid \\
\hline DKB 290 PRO3 x DOW 2B587 PW & VT PRO3ß & Home breeding & Double-cross hybrid \\
\hline DKB 290 PRO3 x MG 600 PW & VT PRO3® & Home breeding & Double-cross hybrid \\
\hline
\end{tabular}

*SS- Saved Seeds. PW- POWERCORE: includes three proteins with insecticide properties (Cry1F, Cry1A.105, Cry2Ab2) for controlling lepidoptera that attack the shoot, and two proteins (CP4 EPSPS, PAT) that give maize plants tolerance to the herbicides glyphosate and glufosinate-ammonium. VT PR03® (PRO3): express the proteins Cry1A.105 and Cry2Ab2, which help to control leaf, culm, and ear plagues; Cry3Bb1, which confers protection against Diabrotica speciosa; and CP4 EPSPS, which grants maize tolerance to glyphosate.

The productivity (in $\mathrm{kg} \mathrm{ha}^{-1}$ ) was estimated considering a 13\% moisture content- a reference value used in all treatments. The mass of 100 seeds was determined by taking four grain samples from each parcel, and then counting 100 intact grains within each set. The result of this procedure was also standardized at a 13\% moisture level.

\subsection{STATISTICAL ANALYSIS}

The resulting data was used to calculate the mean values of each repetition in all evaluations performed. Data were subjected to tests of homogeneity of variance and normal distribution (Kolmogorov Smirnov and Shapiro 
Segregation of The Rr Biotechnology and Agronomical Variables in Single-Cross, Double-Cross, And F2 Hybrids of Maize (Zea Mays L.)

Wilk). For the number of grain rows, the formula $1 /(\mathrm{x}+\mathrm{k})$, where $\mathrm{k}=0.5$, was applied to the original figures. However, the unaltered means were also presented with the letters of the corresponding mean transformation test.

Having the normality and homogeneity of variance been detected, the data were subjected to analysis of variance (ANOVA) with the F test. Once significance was identified, the mean values were compared by the ScottKnott test $(p<0.05)$. All analyses were tackled by the statistical software GENES (CRUZ, 1998). Scheffé test ( $p<0.05)$ was used to compare the treatment groups. The sets were organized into three categories, as specified by the origin of the seeds (Table 1).

The principal component analysis was executed in those variables that had presented statistical difference among the treatments (namely, plant height, ear insertion height, ear size and diameter, number of grain rows, number of grains per row, productivity, and RR-biotechnology segregation). This multivariate analysis made use of the standardized mean values and it was handled by the software PASTE (HAMMER et al., 2001).

A comparative analysis of costs was done for the three seed categories. This evaluation took into consideration only the mean value paid for each hybrid (Table 1), the average productivity of grains, and the market price corresponding to the last three months (April, May, and June 2019) (Lar, 2019).

\section{RESULTS AND DISCUSSIONS}

The experimental groups showed statistical differences among each other, regarding the variables plant and ear insertion height, ear size and diameter, number of grain rows, number of grains per row, productivity, and RRbiotechnology segregation (Table 2). Data showed differences among treatments (cultivars), undesirable results were observed in pirate double-cross hybrid seeds, whereas the commercial ones got superior results in agronomic and economic attributes. Souza et al. (2002) found equivalent results when assessing single-, triple-, and doublecross hybrids and their corresponding endogamic generations.

Table 2: Mean square values and genetic parameters of the significant variables.

\begin{tabular}{|c|c|c|c|c|c|c|c|c|c|}
\hline FV & DF & PH & EIH & EL & ED & NR & NGR & PROD & SEG \\
\hline Block & 3 & 0.01 & 0.006 & 0.744 & 20.196 & 0.369 & 0.369 & 352.056 & 29.078 \\
\hline Treat & 12 & $0.145^{* *}$ & $0.040^{* *}$ & $5.343^{* *}$ & $33.031^{* *}$ & $2.809^{* *}$ & $31.069^{* *}$ & $9,571,662.159^{* *}$ & $408.069^{* *}$ \\
\hline Error & 36 & 0.005 & 0.021 & 0.680 & 2.3310 & 0.469 & 3.695 & 417.770 & 19.284 \\
\hline \multicolumn{2}{|c|}{ Mean } & 2.56 & 1.09 & 16.96 & 51.59 & 15.69 & 31.75 & $6,965.91$ & 10.31 \\
\hline $\mathrm{CV} \%$ & 2.82 & 13.82 & 4.86 & 2.96 & 4.37 & 6.05 & 9.28 & 42.59 \\
\hline $\mathrm{CV}_{\mathrm{g}}(\%)$ & 7.33 & 9.55 & 6.37 & 5.37 & 4.87 & 8.24 & 21.72 & 95.61 \\
\hline $\mathrm{CV}_{\mathrm{g}} / \mathrm{CV}_{\mathrm{e}}$ & 2.6 & 1.54 & 1.31 & 1.81 & 1.12 & 1.36 & 2.34 & 2.25 \\
\hline$\sigma_{g}^{2}$ & 0.0351 & 0.0107 & 1.1658 & 7.675 & 0.5851 & 6.8434 & $2,288,472.961$ & 97.1963 \\
\hline$\sigma_{a}^{2}$ & 0.0052 & 0.0045 & 0.6803 & 2.3315 & 0.4692 & 3.6956 & $417,770.3172$ & 19.2846 \\
\hline$h^{2}$ & & 96.44 & 90.5 & 87.27 & 92.94 & 83.3 & 88.11 & 95.64 & 95.27 \\
\hline
\end{tabular}

** significant at a 1\% probability level, according to the $\mathrm{F}$ test. Plant height (PH), ear insertion height (EIH), ear length (EL), ear diameter (ED), number of grain rows (NR), number of grains per row (NGR), productivity (PROD), RR-biotechnology segregation (SEG).

In this work heritability was estimated in a broad sense. They all scored high (more than 80\%), remarkably for plant height, productivity, and RR-biotechnology segregation. The ratio CVg/CVe of all variables was above 1 , which proves a strong genetic effect and little environmental influence on the variables studied (Table 2). We also determined the heterosis values in all characters (Table 3), where they demonstrated the inferiority of pirate doublecross hybrid seeds in relation to parental performance (Single-cross hybrid).

The attributes plant height and cob insertion are linked to the genetic composition of the cultivars, but they can also be associated with environmental factors. In this study, the hybrid DKB 290 PRO3 exhibited the highest values of plant height and ear insertion height (Table 3). Such outcome supports the findings of Freitas et al. (2017), who also observed the superiority of this cultivar over the others, as for the same variables.

The hybrid AS 1777 PRO3 formed the longest ears $(19.70 \mathrm{~cm})$, substantially differing from the other treatments (Table 3). These findings support those of Batista et al. (2018), who also pointed this cultivar as the one bearing the 
Guilherme Gallas Salvalaggio, Eduardo Franz Berkenbrock, Jhonatan Rafael Wendling Hartmann Hister, Eliane Cristina Gruszka Vendruscolo, Hendrel Vinícius Richter Assis, Vivian Carré Missio, Alan Gregório Martins, and Robson Fernando Missio

longest ears. Conversely, the smallest ones were produced by the treatments that had come from saved seeds/F2 populations or home breeding/double-cross hybrids (T1: MG 580 PW SALVO, T2: MG 30A37 PW SALVO, T3: MG 600 PW SALVO, T4: MG 545 PW SALVO, T10: DKB 290 PRO3 x MG 30A37 PW, T11: DKB 290 PR03 x DKB 285 PR03, and T12: DKB 290 PR03 x 2B587 PW).

For ear diameter, the hybrids DKB 290 PRO3 and MG 580 PW expressed the best values, with averages of 56.64 $\mathrm{mm}$ and $55.63 \mathrm{~mm}$, respectively (Table 3). Similar results were obtained by Olivoto et al. (2018), who analyzed morphological characters and grain yield of maize hybrids under different ambient conditions. They verified that the hybrid DKB 290 PRO3 grew ears with the widest diameter, in all three environments considered.

Regarding the number of grain rows per ear, the most prominent cultivars were the DKB 290 PRO3, the DKB 290 X MG 600, and the MG 580 PW, which scored means of 17.10, 16.60, and 16.50 rows per unit, respectively (Table 3). The performance of these varieties had already been assessed by Silva et al. (2014) and Olivoto et al. (2018). They detected significant differences in the number of grain rows per ear of the hybrids, among which, the DKB 290 PRO3 showed the best values. Kopper et al. (2017) evidenced that, despite meaning more grains per cob, an increase in the number of rows per unit might imply in a lower mass of 1,000 grains. This, however, was not the case in our study, as no statistical difference was detected.

Concerning the number of grains per row, the hybrids MG 30A37 PW, AG 9000 PRO3, AS 1777 PR03, MG 580 PW, and DKB 290 PRO3 x MG 600 PW achieved the best results. The lowest value for this variable was found in the hybrids from an F2 population MG 545 PW SALVO (Table 3). Such outcome endorses the study conducted by Araújo et al. (2017), who perceived differences in the quantity of grains per row of distinct maize hybrids. These quantitative characteristics of maize ears are defined between the phenological stages V4 and V9. Thus, they are paramount for this cereal culture, once they express the joint effect of genotype and environmental aspects (SANGOI et al., 2010).

Table 3: Comparison of the means of the variables, according to the Scott-Knott test.

\begin{tabular}{|c|c|c|c|c|c|c|c|c|}
\hline Treatment/Hybrid & PH $(\mathrm{m})$ & $\begin{array}{c}\text { EIH } \\
(\mathrm{m})\end{array}$ & $\begin{array}{c}\text { EL } \\
(\mathrm{cm})\end{array}$ & $\begin{array}{c}\text { ED } \\
(\mathrm{mm})\end{array}$ & NR & NGR & $\begin{array}{c}\text { PROD (kg ha- } \\
1)\end{array}$ & $\begin{array}{c}\text { SEG } \\
(\%)\end{array}$ \\
\hline MG 580 PW SS* & $2.43 \mathrm{~d}^{* *}$ & $1.01 \mathrm{~d}$ & $16.30 \mathrm{c}$ & $52.11 \mathrm{~b}$ & $15.50 \mathrm{~b}$ & $30.20 \mathrm{~b}$ & $5,918.57 \mathrm{c}$ & $15.66 \mathrm{~b}$ \\
\hline MG 30A37 PW SS & $2.19 \mathrm{f}$ & $0.93 \mathrm{~d}$ & $15.97 \mathrm{c}$ & $50.66 \mathrm{c}$ & $15.60 \mathrm{~b}$ & $28.00 \mathrm{c}$ & $4,652.84 \mathrm{~d}$ & $18.06 \mathrm{~b}$ \\
\hline MG 600 PW SS & $2.34 \mathrm{e}$ & $0.97 \mathrm{~d}$ & $16.00 \mathrm{c}$ & $48.57 \mathrm{~d}$ & $14.70 \mathrm{c}$ & $29.80 \mathrm{~b}$ & $4,950.36 \mathrm{~d}$ & $15.29 \mathrm{~b}$ \\
\hline MG 545 PW SS & $2.47 \mathrm{~d}$ & $1.07 \mathrm{c}$ & $15.57 \mathrm{c}$ & $47.74 \mathrm{~d}$ & $15.10 \mathrm{c}$ & $27.35 \mathrm{c}$ & $5,492.29 \mathrm{~d}$ & $3.07 \mathrm{c}$ \\
\hline MG 580 PW & $2.58 \mathrm{c}$ & $1.11 \mathrm{c}$ & $17.92 \mathrm{~b}$ & $55.63 \mathrm{a}$ & $16.50 \mathrm{a}$ & $34.40 \mathrm{a}$ & $9,244.31 \mathrm{a}$ & $0.00 \mathrm{c}$ \\
\hline MG 30A37 PW & $2.50 \mathrm{~d}$ & $1.08 \mathrm{c}$ & $17.30 \mathrm{~b}$ & $52.37 \mathrm{~b}$ & $15.50 \mathrm{~b}$ & $35.90 \mathrm{a}$ & $8,642.61 \mathrm{a}$ & $0.00 \mathrm{c}$ \\
\hline AS 1777 PRO3 & $2.72 \mathrm{~b}$ & $1.18 \mathrm{~b}$ & $19.70 \mathrm{a}$ & $47.19 \mathrm{~d}$ & $13.90 \mathrm{~d}$ & $34.80 \mathrm{a}$ & $8,437.66 \mathrm{a}$ & $0.00 \mathrm{c}$ \\
\hline AG 9000 PR03 & $2.50 \mathrm{~d}$ & $0.95 \mathrm{~d}$ & $17.97 \mathrm{~b}$ & $49.75 \mathrm{c}$ & $16.00 \mathrm{~b}$ & $35.20 \mathrm{a}$ & $7,654.65 \mathrm{~b}$ & $0.00 \mathrm{c}$ \\
\hline DKB 290 PR03 & $2.98 \mathrm{a}$ & $1.33 \mathrm{a}$ & $17.32 \mathrm{~b}$ & $56.64 \mathrm{a}$ & $17.10 \mathrm{a}$ & $29.70 \mathrm{~b}$ & $9,151.84 \mathrm{a}$ & $0.00 \mathrm{c}$ \\
\hline DKB 290 PR03 x MG 30A37 PW & $2.62 \mathrm{c}$ & $1.18 \mathrm{~b}$ & $16.55 \mathrm{c}$ & $51.81 \mathrm{~b}$ & $15.50 \mathrm{~b}$ & $31.50 \mathrm{~b}$ & $6,640.18 \mathrm{c}$ & $27.86 \mathrm{a}$ \\
\hline DKB 290 PR03 x DKB 285 PR03 & $2.61 \mathrm{c}$ & $1.09 \mathrm{c}$ & $15.62 \mathrm{c}$ & $50.97 \mathrm{c}$ & $15.90 \mathrm{~b}$ & $31.10 \mathrm{~b}$ & $6,640.26 \mathrm{c}$ & $15.64 \mathrm{~b}$ \\
\hline DKB 290 PR03 x D0W 2B587 & $2.68 \mathrm{~b}$ & $1.12 \mathrm{c}$ & $16.92 \mathrm{c}$ & $53.12 \mathrm{~b}$ & $16.10 \mathrm{~b}$ & $31.30 \mathrm{~b}$ & $6,365.62 \mathrm{c}$ & $23.18 \mathrm{a}$ \\
\hline PW & & & & & & & & \\
\hline DKB 290 PR03 x MG 600 PW & $2.55 \mathrm{~d}$ & $1.04 \mathrm{c}$ & $17.30 \mathrm{~b}$ & $54.05 \mathrm{~b}$ & $16.60 \mathrm{a}$ & $33.55 \mathrm{a}$ & $6,765.52 \mathrm{c}$ & $15.26 \mathrm{~b}$ \\
\hline Heterosis & -0.12 & -0.025 & -0.76 & -2.695 & -0.8 & -1.3 & $-2,257.05$ & 27.86 \\
\hline
\end{tabular}

*SS- Saved Seeds. **means followed by different letters, in the column, statistically differ among themselves, according to the Scott-Knott test $(\mathrm{p} \leq 0.05)$. Plant height (PH), ear insertion height (EIH), ear length (EL), ear diameter (ED), number of grain rows (NR), number of grains per row (NGR), productivity (PROD), RR-biotechnology segregation (SEG). Heterosis: calculated with basis on the performance of the crossing (F1) between DKB 290 X MG 30A37, considering the parental averages DKB 290 PRO 3 (P1) and MG 30A37 PW (P2).

The grain productivity was distinct among the hybrids appraised, allowing the Scott-Knott test to arrange them into four groups (Table 3 and Figure 1A). The group with most impressive productivity delivered between 8,437.66 and 9,244.31 kg of grains. ha-1 and the hybrids were classified in the following order: MG 580 PW, DKB 290 PR03, MG 30A37 PW, and AS 1777 PRO3 - all of them grown from seeds of commercial hybrids. The second group enclosed only the cultivar AG 9000 PRO3, with 7,654.65 kg ha-1. The third group comprised the cultivars DKB 290 PRO3 x MG 600 PW, DKB 290PRO 3 x DKB 285PRO 3, DKB 290PRO 3 x MG 30A37 PW, DKB 290 PRO3 x DOW 2B587 PW, and 
MG 580 PW SALVO, whose production varied between 5,918.57 and 6,765.52 kg ha-1. The lowest productivities were obtained by the cultivars MG 30A37 PW SALVO, MG 600 PW SALVO, and MG 545 PW SALVO (Table 3 and Figure 1A). Ecco et al. (2014), Pinotti et al. (2014), Kuneski et al. (2017), and Gomes et al. (2019) also discerned variations in productivity among different maize cultivars.

According to data disclosed by the National Supply Company (CONAB, 2019), the 2018/2019 crop is expected to yield an average of 5,750 kg ha-1- in Paraná state. In this sense, the varieties raised from saved seeds (F2 population) or home breeding (double-cross hybrids) showed productivity values rather close to this number (Figure 1A). On the other hand, hybrids from commercial seeds produced more 2,876.21 kg ha-1on average.

The high productivity of the cultivars (compared to the state average) could be explained by the fact that the sowing was performed early (on January 23, 2019) providing the crop more hot days and sunlight hours. These conditions, in association with favorable climate and good agronomical management practices, might have contributed to the superior result. Pinotti et al. (2014) stated that the productivity performance of maize results from the union of genetic factors of the cultivars, edaphoclimatic conditions, and solar radiation reaching the culture.

In this work, the general average of grain productivity of the experiments was of $6,965.90 \mathrm{~kg}$ ha-1, a value that surpassed those of hybrids originated from saved seeds or home breeding. The commercial seeds, such as the cultivar MG 580 PW, presented values up to 2,278.4 kg ha-1 above the average (Figure 1A).

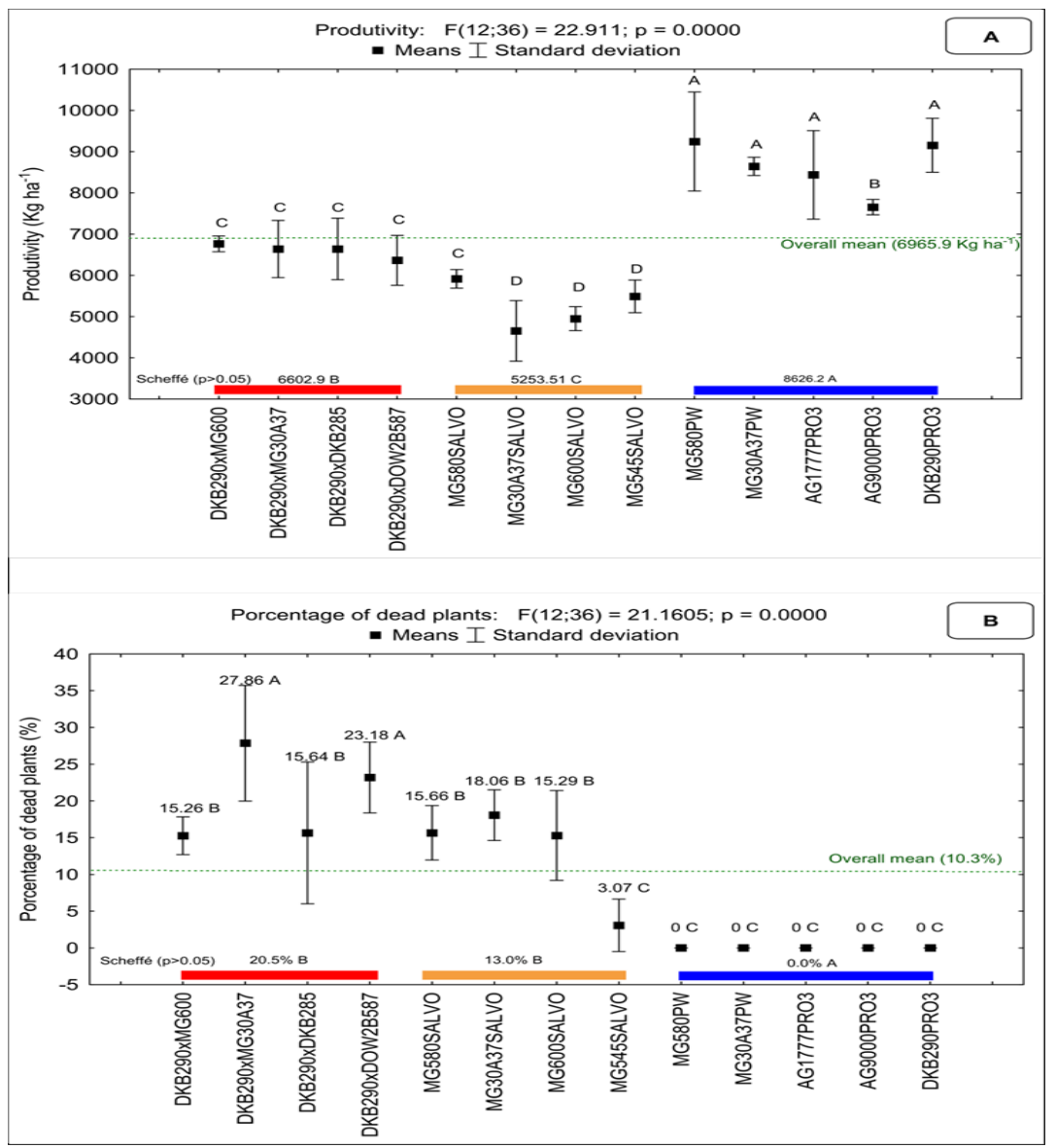

Figure 1: Mean grain productivity (A) and RR-biotechnology segregation, as evaluated by the percentage of dead plants after application of the herbicide Glyphosate $®(B)$, according to the Scott-Knott test (among treatments) and Scheffé test (among seed categories), both at a 5\% probability level.

To assess the percentage of RR-biotechnology segregation, the population of plants susceptible to the herbicide glyphosate (an inhibitor of the enzyme EPSPS) was quantified within each treatment. Single-cross hybrids originated from commercial seeds showed no mortality. This fact was already expected, as certified seeds assure to farmers both quality and efficiency in the aforementioned biotechnology. The cultivar MG 545 PW SALVO statistically did not differ from the previous group and it showed a 3\% segregation, in relation to the initial plant population (Figure 1B). 
The most significant segregation values were found in the double-cross hybrids produced from DKB 290 PRO3 x MG 30A37 PW and DKB 290 PRO 3 x DOW 2B587 PW (27.86 and 23.18\%, respectively). The remaining cultivars had intermediate segregation, with an average of $15.98 \%$ of plants killed by the agrochemical (Figure 1B). These results can be easily explained by the Mendelian genetics, as it seems to be a case of gene dominance. Thus, the presence of dominant alleles in the locus grants tolerance to glyphosate, whereas recessive homozygous alleles imply in susceptibility to the herbicide (BUENO et al., 2006).

Commercial seeds of single-cross hybrids generate a homogeneous F1 population formed by heterozygotes. This, in association with the RR biotechnology, bestows tolerance to glyphosate upon $100 \%$ of the individuals. On the other hand, double-cross hybrids (from home breeding) originates heterogeneous populations, with a mixed progeny, composed of $25 \%$ dominant homozygotes, $50 \%$ heterozygotes, and $25 \%$ recessive homozygotes (1:2:1). Thus, $25 \%$ of the individuals are expected to be susceptible to the herbicide. The segregation is also valid in cases of seeds saved from the farmer's own production (F2 population), as it was verified in our work (Figure 1B).

The behavior of the seed groups (commercial, saved, and home-bred) was compared through contrast analyses by Scheffé test (Figure 2)
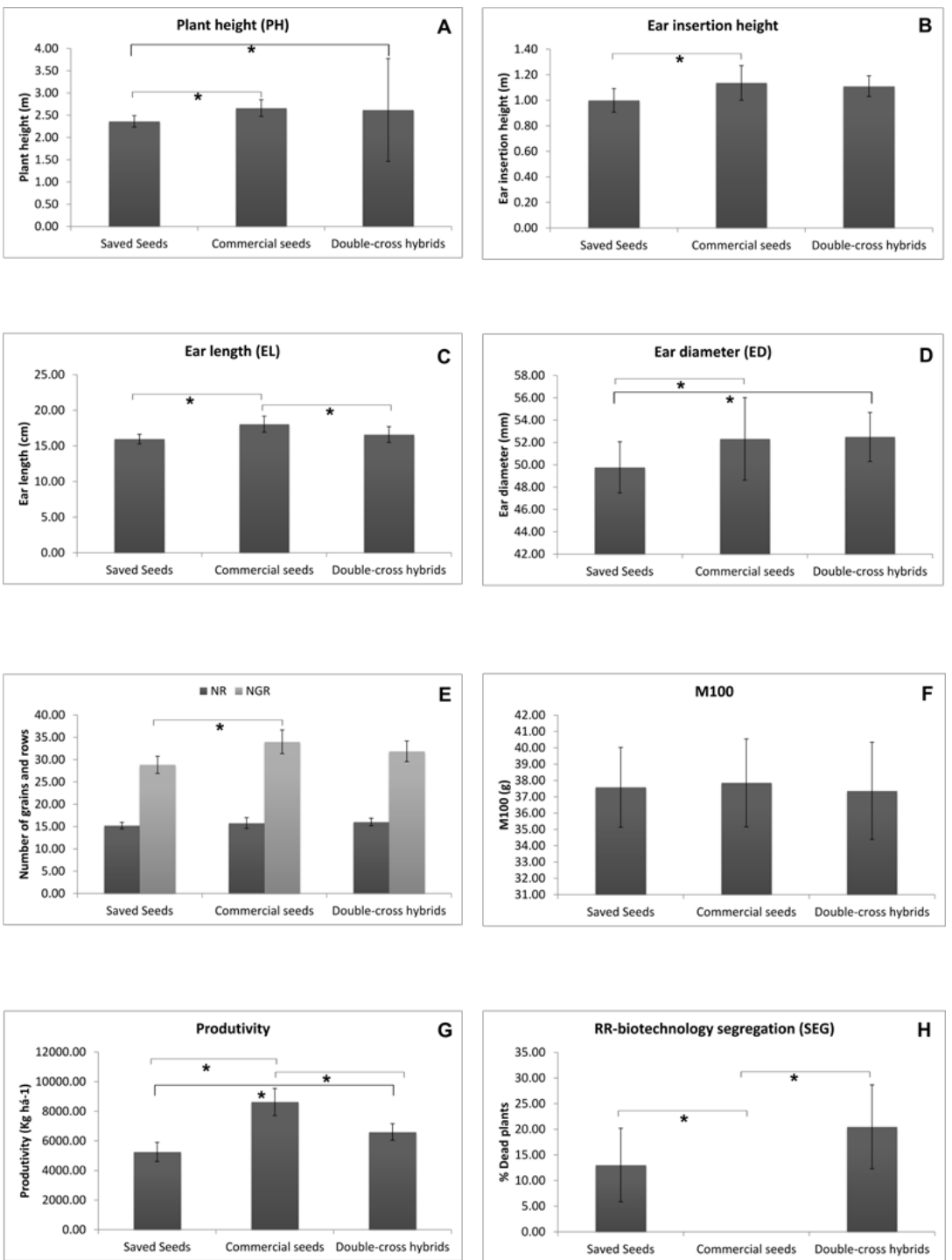

Figure 2: Comparative among the seed categories (origin), according to the contrast resulted - Scheffé test. A: Plant height (m); B: ear insertion height $(\mathrm{m})$; C: ear length $(\mathrm{cm})$; D: ear diameter $(\mathrm{mm})$; E: number of grain rows (NR) and number of grains per row (NGR); F: mass of 100 seeds (g); G: productivity (kg ha-1); H: RR-biotechnology segregation, as assessed by the percentage of dead plants after application of the herbicide Glyphosate ${ }^{\circledR}$. *: indicates significance among seed categories (Scheffé test, $\mathrm{p}<0.05$ ). 
The group of hybrids from commercial seeds had a superior performance in all variables appraised, remarkably in productivity and RR-biotechnology segregation (Figures $2 \mathrm{G}$ and $2 \mathrm{H}$ ). Besides, these hybrids yielded about $2,698.2$ $\mathrm{kg}$ ha-1 more grains than the other treatments (Figure $2 \mathrm{G}$ ) - precisely 2,023.3 kg ha-1 more than the home-bred hybrids and 3,372.7 kg ha-1 more than those produced from saved seeds (Figure $2 \mathrm{G}$ ). The quality of the ears representing each group attested the differences related to uniformity, which indicates genetic segregation in this class of seeds (Figure 3).

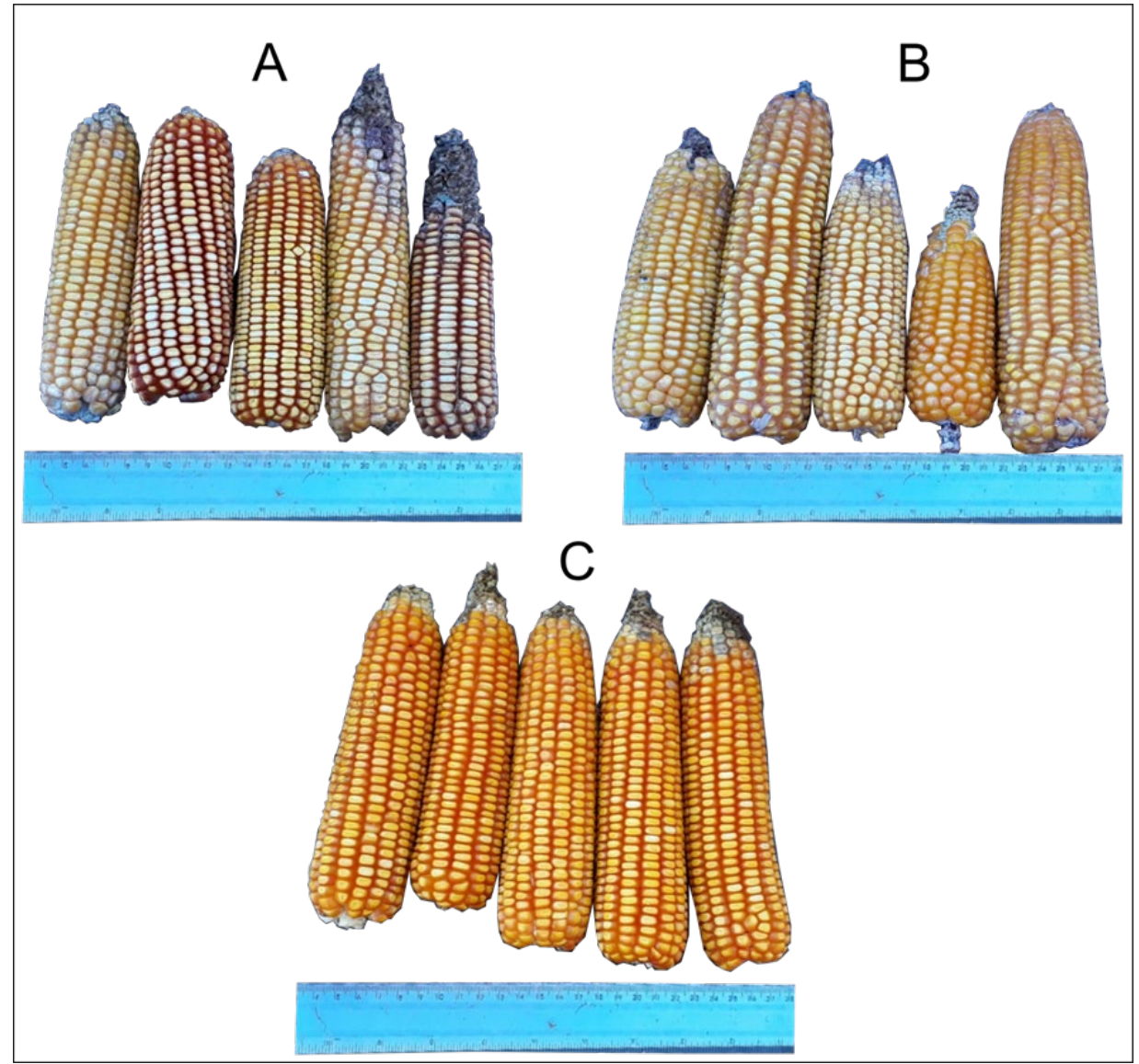

Figure 3: Representative maize ears of hybrids produced from home breeding/double-cross hybrids (pirate seeds) (A), saved seeds/F2 population (B), and commercial hybrids (C).

The RR-biotechnology segregation in the double-cross hybrids and saved seeds was of $16.76 \%$; whereas it was null $(0 \%)$ in hybrids from commercial seeds (Figure 2H). This latter group also provided the best result, with $20.50 \%$ less segregation than the home-bred seeds (Figure 2H). Acosta et al. (2002) pointed out that seeds coming from hybrid maize crops exhibit low segregation frequencies, mostly due to the low productivity, grain health, and high rates of plant lodging and culm breakage aspects deemed as relevant by farmers when choosing a cultivar.

It was possible to spot differences in both quality and uniformity of representative ears of the hybrids from commercial, home-bred, and saved seeds (Figure 3). The inferiority of the group grown from home-produced seeds became evident, as they bore malformed, uneven ears, and low-quality grains. This aftermath corroborates the work of Acosta et al. (2004), who stated that varieties with open pollination and double-cross hybrids formed irregular stands, with short plants, which are susceptible to breakage and lodging.

Through the principal component analysis (Figure 4), the treatments were sorted as for their seed origin (commercial, saved, or home breeding). The first two components explained $41.50 \%$ and $21.60 \%$ of data variability, respectively (Figure 4). Grain productivity and the features linked to yield - such as mass of 100 seeds (M100), ear length (EL), and number of grains per row (NGR) - were more prominent in hybrids from commercial seeds (MG 580 PW, DKB 290 PR03, MG 30A37 PW, AS 1777 PR03, and AG 9000 PR03). These results support those of Machado et al. (2008), who proved single-cross hybrids to be superior to the double-cross ones, regarding grain production. 


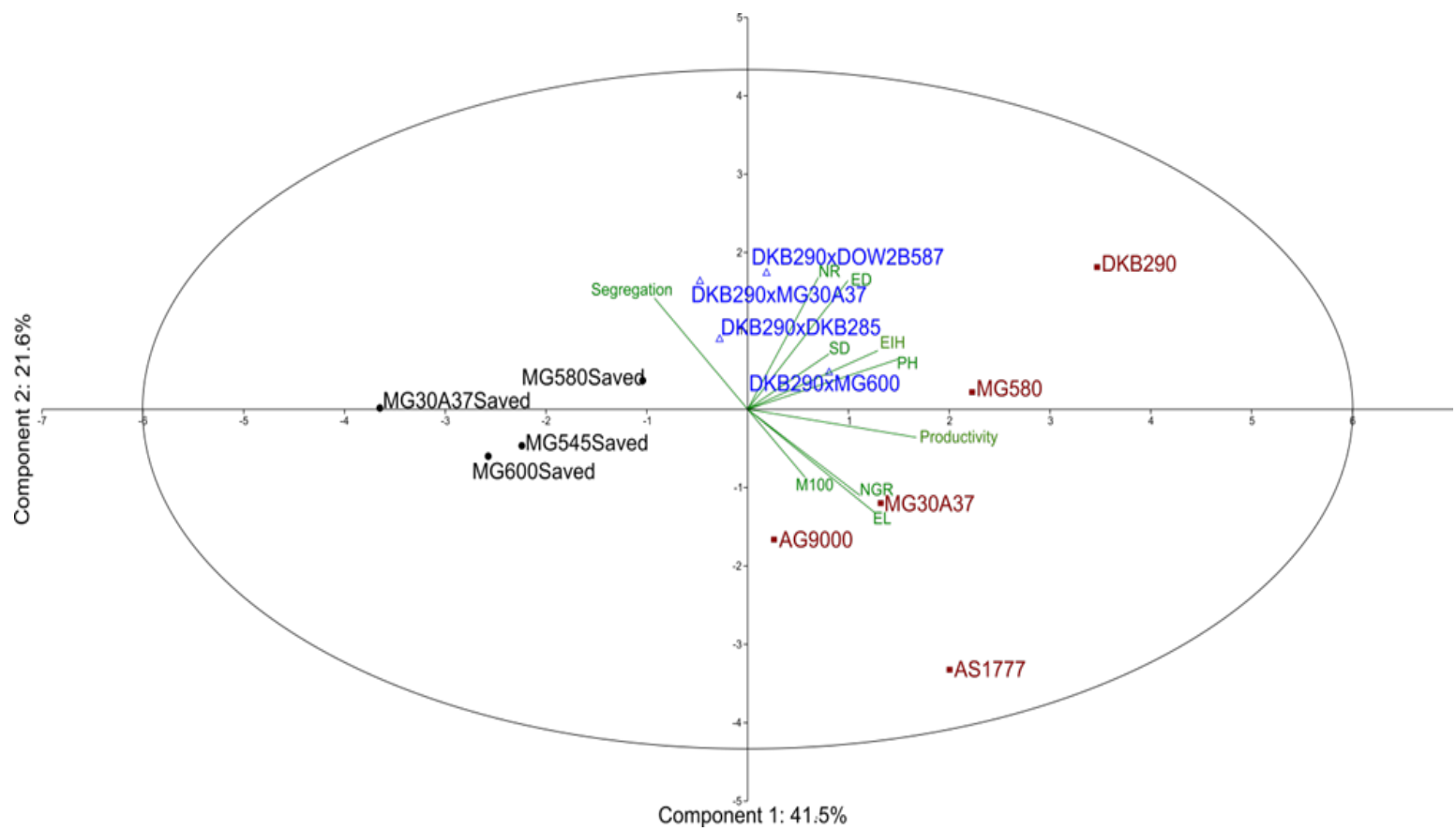

Figure 4: Principal component analysis (PCA) of all variables and treatments. Seeds of commercial singlecross hybrids are depicted in red, saved seeds/F2 population are in black, and seeds from home breeding/doublecross hybrids (pirate seeds) are in blue. The variables are represented in green.

On the other hand, the attributes plant height (PH), ear insertion height (EIH), culm diameter (CD), ear diameter (ED), and number of grain rows (NR) were stronger in the group of hybrids from home-breeding (DKB 290 PRO3 x DKB 285 PW, DKB 290 PRO3 x MG 600 PW, DKB 290 PR03 x MG 30A37 PW, and DKB 290 PR03 x D0W 2B587 PW). Such relationship can be explained by the fact that all crossings had the hybrid DKB 290 PRO3 as a parent. This specific variety is characterized by having tall plants, thick and healthy culms, large cobs, and more grain rows (DEKALB, 2017). Nevertheless, the segregation of the RR biotechnology was highly correlated to the groups of cultivars from saved and home-bred seeds, once they showed susceptibility to the herbicide glyphosate.

The cost analysis considered each category as for the average price of 60,000 seeds, the average grain production, and the average market price in the previous trimester (Table 4). Even though saved and home-bred seeds had the lowest purchase value, they yielded significantly less. This fact compensates the costs of buying commercial seeds, whose net revenue surpassed that of the saved seeds by USD 302.49, and also that of the home breeding ones by USD 158.29, values that are in accordance to Passos et al. (2018). They also proved that, despite having a costly production due to the high purchase prices, the commercial varieties often lead to a positive balance.

Table 4: Cost-benefit analysis of using each seed category.

\begin{tabular}{|c|c|c|c|c|}
\hline Seed category & $\begin{array}{c}\text { Cost of 60,000 seeds* } \\
\text { (USD) }\end{array}$ & $\begin{array}{c}\text { Productivity } \\
\left(\mathrm{kg} \mathrm{ha}^{-1}\right)\end{array}$ & $\begin{array}{c}\text { Maize price** } \\
\text { (USD) }\end{array}$ & $\begin{array}{c}\text { Total net ha }^{-1} \\
\text { (USD) }\end{array}$ \\
\hline Commercial- Single-cross hybrids & 113.80 & $8,626.21$ & USD 7.63 & 930.54 \\
\hline $\begin{array}{c}\text { Home breeding- Double-cross } \\
\text { hybrids }\end{array}$ & 27.13 & $6,602.90$ & USD 7.63 & 772.25 \\
\hline \begin{tabular}{c} 
Saved- F2 Population \\
\hline
\end{tabular} & 7.97 & $5,253.51$ & USD 7.63 & 628.05 \\
\hline
\end{tabular}

${ }^{*}$ Considering the United States Dollar to Brazilian Real exchange rate equal to 4.13; **mean of the prices on 06/30,05/30, and 04/30, 2019 (Source: canalrural.uol.com.br/cotacao/milho/).

According to Acosta et al. (2002), farmers claim to recognize the superior potential of commercial single-cross hybrids when it comes to productivity. Yet, they opt for sowing home-produced seeds, not only due to their affordability, but also because they typically have little land available for cultivation. Notwithstanding, in our study, 
we proved that the final production of commercial hybrids could make up for any higher initial investment in highquality, certified seeds.

\section{CONCLUSIONS AND RECOMMENDATIONS}

The diverse origin of the seeds used in this experiment had a significant effect on agronomic and economic characteristics. Single-cross hybrids grown from commercial seeds presented the highest productivities and the lowest genetic segregation rates. They also displayed high uniformity.

Regarding the RR-biotechnology, the pirate seeds (from home breeding double-cross hybrids) showed segregation, with up to $30 \%$ of mortality - which makes the application of the herbicide glyphosate unfeasible. This fact hinders weed management, thus reducing grain productivity.

Lastly, the cost analysis allowed to conclude that the acquisition of commercial seeds of single-cross hybrids is worthwhile and profitable, as they offer higher safety and quality.

\section{SOURCES OF FUNDING}

This research received no specific grant from any funding agency in the public, commercial, or not-for-profit sectors.

\section{CONFLICT OF INTEREST}

The author have declared that no competing interests exist.

\section{ACKNOWLEDGMENT}

We would like to thank the Conselho Nacional de Desenvolvimento Científico e Tecnológico - CNPq for the financial support to author Hendrel Vinícius Richter Assis and to the project Melhoramento Genético do milho (Zea mays L.).

\section{REFERENCES}

[1] Acosta, A., Lange, A., Viola, E., Bonfada, F., Doro, C., Alves, F., Barcellos, L. (2002). Perfil de propriedades e produtores de milho varietal da Embrapa em unidades de observação/validação conduzidas pela Emater no Estado do Rio Grande do Sul. In: Congresso Nacional de Milho e Sorgo, Florianópolis: ABMS - Embrapa Milho e Sorgo, p. 6.

[2] Acosta, A., Rosinha, R., Lange, A., Viola, E., Doro, C., Gadea, C., Germano, D., Bonione, D., Alves, F., Bonfada, F., Barcellos, L. A., Garcia, T., Righi, V., Bossle, W. (2004). Transferência de tecnologia e fomento de variedades de milho em propriedades familiares: resultados da cooperação entre Embrapa e Emater/RS - Ascar no Rio Grande do Sul de 1995 a 2002. Extensão Rural e Desenvolvimento Sustentável, 1, 30-37.

[3] Alessi, M. O., Raupp, D. D. S., Gardingo, J. R. (2009). Caracterização do processamento da farinha de milho biju para o aproveitamento dos subprodutos. Ciências Exatas e da Terra, Ciências Agrárias e Engenharias, 9, 3139.

[4] Araújo, L.S., Silva, L.G.B., Silveira, P.M., Rodrigues, F., Lima, M.L.P., Cunha, P.C.R. (2017). Desempenho agronômico de híbridos de milho na região sudeste de Goiás. Agro@mbiente On-line, 10, 334-341.

[5] Abrasem-Associação Brasileira De Sementes e Mudas. (2019). Alto Índice de sementes piratas ameaça conquistas da agricultura brasileira. Brasília. http://www.abrasem.com.br/alto-indice-de-sementes-piratasameaca-conquistas-da-agricultura-brasileira/ Accessed on 13 June 2019.

[6] Batista, V. V., Link, L., Giaretta, R., Silva, J. S., Adami, P. F. (2018). Componentes de rendimento e produtividade de híbridos de milho cultivados em safrinha. Pesquisa Aplicada \& Agrotecnologia, 11, 67-75. 
Guilherme Gallas Salvalaggio, Eduardo Franz Berkenbrock, Jhonatan Rafael Wendling Hartmann Hister, Eliane Cristina Gruszka Vendruscolo, Hendrel Vinícius Richter Assis, Vivian Carré Missio, Alan Gregório Martins, and Robson Fernando Missio

[7] Bernini, C. S. (2011). Avaliação agronômica e heterose de híbridos de populações F2 de milho, visando nova alternativa para o estado de São Paulo. 2011. 84 p. Dissertação (Mestrado em Agricultura Tropical e Subtropical) - Setor de Genética, Melhoramento Vegetal e Biotecnologia, Instituto Agronômico, Campinas.

[8] Bueno, L. C. S., Mendes, A.N.G., \& Carvalho, S.P. (2006). Melhoramento Genético de Plantas: Princípios e Procedimentos. Lavras: UFLA, 319p.

[9] Cib-Conselho de Informações Sobre Biotecnologia. (2010). Guia do milho: tecnologia do campo à mesa. http://www.cib.org.br/pdf/guia_do_milho_cib.pdf/ Accessed on 13 May 2019.

[10] Conab-Companhia Nacional de Abastecimento. Acompanhamento da Safra de Brasileira de grãos. nono levantamento: Safra 2018/2019. 6, 9, junho 2019. https://www.conab.gov.br/infoagro/safras/graos/monitoramento-agricola.pdf/ Accessed on 21 June 2019.

[11] Cruz, J. C., Pereira, F. T. F., Pereira Filho, I. A., Oliveira, A. C., Magalhaes, P. C. (2007). Resposta de cultivares de milho à variação em espaçamento e densidade. Revista Brasileira de Milho e Sorgo, 6, 60-73.

[12] Cruz, C. D. (1998). Programa GENES: Aplicativo Computacional em Estatística Aplicada à Genética (GENES Software for Experimental Statistics in Genetics). Genetics and Molecular Biology, 21-1. https://dx.doi.org/10.1590/S1415-47571998000100022.

[13] Dekalb (2017). DKB 290 PRO 3. Disponível em: https://www.dekalb.com.br/pt-br/nossosprodutos/hibridos-milho/safrinha/dkb-290.html/ Accessed on 23 June 2019.

[14] Duarte, J., Mattoso, M., Garcia, J. C. Milho: Importância Socioeconômica. Agência Embrapa de Informação Tecnológica.

ttps://www.agencia.cnptia.embrapa.br/gestor/milho/arvore/CONTAG01_8_168200511157.html Accessed on 23 June 2019.

[15] Ecco, M., Rosset, J. S., Rampim, L., Costa, A. C. T., Carmo Lana, M., Stangarlin, J. R., Sarto, M. V. M. (2014). Características agronômicas de híbridos de milho segunda safra submetidos à aplicação de fungicida. Agrarian, 7, 504-510.

[16] Freitas, R. S., Duarte, A. P., Sawazaki, E., Leão, P. C. L, Miguel, F. B., Cavichioli, J. C., Ticelli, M., Cazentini-Filho, G., Fornasieri Filho, D., Mingette, F. L. C., Pessinatti, F. A., Borges, W. L. B., Vitor, L.G., Tokuda, F. S., Oliveira, A. L., Almeida, P. P. (2017). Desempenho agronômico de cultivares de milho na região norte/oeste do estado de São Paulo - safras 2015/16 e 2016/17. Nucleus, 14,113-120. https://doi: 10.3738/1982.2278.2828.

[17] Godoi, R. E. Z. (2008). Produção de sementes de milho híbrido. Seed News, 12, 5.

[18] Gomes, L. L., Buso, W. H. D., Lima, J. B., Matos, H. G., Leão Junior, L. A. (2019). Evaluation of corn hybrids performance in two locations of Goiás. Revista de Agricultura Neotropical, 6, 8-16.

[19] Hammer, Ø., Harper, D. A., Ryan, P. D. (2001). PAST: paleontological statistics software package for education and data analysis. Palaeontologia Electronica, 4, 9.

[20] Kopper, C. V., Meert, L., Krenski, A., Borghi, W. A., Oliveira Neto, A. M., Figueiredo, A. S. T. (2017). Produtividade de milho segunda safra em função de diferentes velocidades de semeadura e densidade de plantas. Pesquisa Agropecuária Pernambucana, 22, 1-6.

[21] Kuneski, H. F., Sangoi, L., Coelho, A. E., Durli, M. M., Leolato, L. S., Voss, R., Panison, F. (2017). Desempenho Agronômico de Híbridos de Milho no Alto Vale do Itajaí - SC. Revista da Jornada de Pós-Graduação e PesquisaCongrega Urcamp, 14, 1146-1159.

[22] Lacey, H. (2000). As sementes e o conhecimento que elas incorporam. São Paulo em Perspectiva, 14, 53-59.

[23] Lar-Cooperativa Agroindustrial (2019). Agronegócio. http://www.lar.ind.br/v4/agronegocio/index.php/ Accessed on 27 June 2019.

[24] Machado, J. C., Souza, J. C., Ramalho, M. A. P., Lima, J. L. (2008) Estabilidade de produção de híbridos simples e duplos de milho oriundos de um mesmo conjunto gênico. Bragantia, 67, 627-631.

[25] Martin, T. N., Tomazella, A. L., Cícero, S. M., Neto, D. D., Favarin, J. L., Júnior, P. A. V. (2007). Questões relevantes na produção de sementes de Milho-primeira parte. Revista da FZVA, 14, 119-138.

[26] Olivoto, T., Carvalho, I. R., Nardino, M., Ferrari, M., Pelegrin, A. J., Szareski, V. J., Souza, V. Q. (2018). Caracteres morfológicos e rendimento de grãos de híbridos simples de milho em diferentes ambientes. Revista de Ciências Agroveterinárias, 17, 462-471.

[27] Passos, A. M. A., Botelho, F. J. E., Godinho, V., Aker, A. M., Quintino, S. M. (2018). Desempenho agronômico e econômico de genótipos de milho em safrinha tardia na região sudoeste da Amazônia. Enciclopédia Biosfera, 15, 376-389.

International Journal of Research -GRANTHAALAYAH 
[28] Pereira Filho, I. A., Alvarenga, R. C., Gotijo Neto, M. M., Oliveira, M. F., Matrangolo, W. J. R. Cultivo do milho. Embrapa $\quad$ Milho $\quad$ e $\quad$ Sorgo, 2008. https://ainfo.cnptia.embrapa.br/digital/bitstream/item/35209/1/Cultivares.pdf/ Accessed on 15 May 2019.

[29] Pinotti, E. B., Bicudo, S. J., Godoy, L. D., Bueno, C. (2014). Características agronômicas de cultivares de milho em função de populações de plantas e épocas de semeadura. Revista Científica Eletrônica de Agronomia, 25, 17-33.

[30] Pioneer. RoundupReady Milho $2^{\text {тм }}$. http://www.pioneersementes.com.br/biotecnologia/roundup-ready2/ Accessed on 27 May 2019.

[31] Sangoi, L., Schweitzer, C., Schmitt, A., Pícoli Jr, G. J., Vargas, V. P., Vieira, J., Carniel, G. (2010). Perfilhamento e prolificidade como características estabilizadoras do rendimento de grãos do milho em diferentes densidades. Revista Brasileira de Milho e Sorgo, 9, 254-265.

[32] Silva, A.F., Schoninger, E.L., Caione, G., Kuffel, C., Carvalho, M. A. C. (2014). Produtividade de híbridos de milho em função do espaçamento e da população de plantas em sistema de plantio convencional. Revista Brasileira de Milho e Sorgo, 13, 162-173.

[33] Silva, J. M. D. (2011). Panorama geral da certificação de sementes no Estado de Goiás. Dissertação (Mestrado em Ciência e Tecnologia de Sementes) - Universidade Federal de Pelotas Universidade Federal de Pelotas, Pelotas, $39 \mathrm{p}$.

[34] Souza, J., Ribeiro, P. H. E., Junior, O. M., Moreto, A. L. (2002). Avaliação de híbridos simples, triplo e duplos e suas respectivas gerações endogâmicas. In: Congresso Nacional de Milho e Sorgo, 2002, Florianópolis: UFLDepartamento de Biologia, p. 37. 